\title{
Local Governments and Government of Cities in Turkey
}

\author{
Nazım Kartal, Assistant Professor \\ đ̈rahim Çeçen University, Agrı, Turkey \\ Email: nazimkartal@gmail.com \\ Gökhan Tuncel, Assistant Professor \\ Inonu University, Malatya,Turkey \\ Email: gokhan.tuncel@inonu.edu.tr \\ Oguzhan Göktolga (Corresponding Author) \\ Inonu University, Malatya, Turkey \\ Email: oguzhan.goktolga@inonu.edu.tr
}

Accepted: January 16, 2015

Doi:10.5296/jpag.v5i1.6858 URL: http://dx.doi.org/10.5296/jpag.v5i1.6858

\begin{abstract}
At this study, local government structure of Turkey is tried to be analysed. Urban administration of Turkey may be analysed three dimensionally: First dimension is central government and the city; the second is provincial organizations of central government and the third dimension is local governments and city. Therefore, when talking about "administration of cities in Turkey", central government, its local organizations and especially the local governments should be mentioned. In this context, at this study initially cities in Turkey will be examined from the perspective of administration, then, central administration and central administration's provincial organiations will be examined from the perspective of city governmnet. Finally two local government structures, "special provinicial administration" and "municipalities" will be examined.
\end{abstract}

Keywords: Turkey, Local government, central administration, special provincial administration 


\section{Introduction}

The geopolitical position of the country, its historical perspective and cultural structure have paved the way for the State to be the main identifier on economy, politics, social and cultural structure in Turkey. From its foundation to 16 th, even to 17 th century, Ottoman State was a State which was getting larger day bay day becauyse of its conquest s. However, beginning from 16th centuryit was not able to keep up with the developments occured in Europe. Consequently, the State entered in en era of discontinuance and then, regression. Loss of some of the lands and its power were other consequences. Land loss which was the consequence of French Revolution and which initially began in Balkans and then Arab lands, resulted in a nationalization process in almost every area in the country. Nationalization activities which began in the late Ottoman Era and continued in early Repuclican era, perceived the divergent and the local as potential threats. And these nationalization activities have been carried out at a jacobin and hard nationalist manner.

Diffrent from the case occured in the West, the process in which the authority of the Padishah (Ottoman Ruler) began to weaken was not based on an organised class structures. Even after this process, the class structures have not been identifier in the country. In the weakening process, initially foreign dynamics were influential, but in time, public bureaucracy has begun to be influential at administration of the country. The persistence of extra ordinary circumstances have brouht the security out in the country and this in turn led to an increase in influence of the military at administration of the country.

Westernization and modernization efforts have direct or indirects affects on the political, social and cultural developments in Turkey. Foundation of the modern nation sate and efforts to create ctizens suitable for the new regime, were the primary activity areas of the bureaucratic elitists who were in the power. From this perspective, with foundation of the Republic, planning of the urban space has an important role in the shaping out of the new occuring society. At this study, aims of shaping out the new society via planning of urban space, urbanization process and urban government in Turkey are tried to be analyzed from various perspectives.

The history of urbanization in Turkey, beginning with the Republican Era can be devided into three periods: 1) 1923-1950 Urbanization of the nation-state, 2) 1950-1980 urbanization of labor, 3) 1980 and onwards urbanization of the capital. The most important identifier of the urbanization is the move of the capital city from Istanbul to Ankara, where was a piece of desert lanf in inner Anatolia. The reason for selection of Ankara as the capital city, is not only choosing a "safe city", but also the wish of the founders to break the old ties with the former regime. Because Ottoman cities had an aspect of semi-autonomous, delicate against the controle of the central government, lack of strong network of transportation, and cities were spatially seperated on the basis of relgious differences (gengül, 2009: 106-110). Nonetheless, the new regime wanted to unify the city in terms of ethnicity and religion. Homogenization process made the construction of the infrastructures of transportation and information necessary which would spread the new cultural and ideological codes of the newnation-state to whole of the country. Since Turkey was a country of agriculture, measures which would 
prevent people from moving to urban areas were tried to be taken. For this period, it may be said that the State realised important changes on planning of the urban spaces. In 1930s Acts about Municipalities, general hygiene, buildings and ways, carrying out of Engineering and architecturing profesions were issued so that regulations related to urban areas were performed (Tekeli, 2009: 158).

1950-1980 period was the era when immigration from rural to urban areas increased because of the reasons such as modernization in agriculture, increase in the number of tractors, decrease in fertility of land, etc. Facts such a rapid and unplanned urbanization, immigration, urban poverty and slum houses are the facts which characterize this period. With the period of planned economy, which occured after 1960 Coup d'Eta, speed of industrialization accelarated, and this in turn, resulted in urban pollution and an intensive housing problem. In relation to these problmes, within State Planning Organization (SPO), some efforts were spent about urban planning. However, since the priority of the State was industrial investments rather than a planned urbanization, a supportive attitude against planned urbanization was not exhibited.

With economic liberalization processes began after 1980, cities have again gained importance because of the various functions they have. Urbanization process after 1980 is characterised with organization practices of the capital in urban places as is the case at neoliberal economic policies. Infrastructure and superstructure investments of big agencies like Housing Development Administration of Turkey (TOKI) have been the main components of transformation process of urban spaces. Another reason fort his aptitude which was operative at urbanization of Turkey is that, global city perception had a legitimative role in transformation of the cities.

Urban administration of Turkey may be analysed three dimensionally: First dimension is central government and the city; the second is provincial organizations of central government and the third dimension is local governments and city. Therefore, when talking about "administration of cities in Turkey", central government, its local organizations and especially the local governments should be mentioned. In this context, at this study initially cities in Turkey will be examined from the perspective of administratin, then, central administration and central administration's provincial organiations will be examined from the perspective of city governmnet. Finally two local government structures, "special provinicial administration" and "municipalities" will be examined.

\section{City: Concept and Fact in Turkey}

When the word "city"is used, it evokes something in every mind. But it is difficult to determine, circumscribe and classify the city. The concep of "city" may be defined in different ways regarding to the criteria used. When we perceive a settlement from the perspectives of sociology, economy, geography or administration, it will result in different conceptualizations with respect to your area of study (Yavuz, KeleĢ\&Geray, 1973: 23).

Population, as it is the case all over the world, is one of the most importants variables in determination and definition of the city. (Yavuz, KeleĢve Geray, 1973: 23). For instance, in 
documents of OECD, administrative units which has a population density of less than 150 person per kilometer have been accepted as "rural" areas and units which have a population density of more than 150 person per kilometer have been accepted as "urban" areas. In Turkey, a research is performed in 1982 by State Planning Organization (SPO) ${ }^{\mathrm{i}}$ on cities. At this research, 28 cirteria such as population, empleoyment areas of the population, number of commercial firms, number of bank branches, number of telephone subscribers have been considered and it is aggreed that areas which have a population of more than 20.000 people have been accepted as urban areas, and the areas which have a population of less than 20.000 should be accepted as rural areas (Bayındırlık ve Ġskan Bakanlığı, 2009: 322).

An other dominant variable used for rural-urban difference is "administrative status". In Turkey, in addition to the criterion of population of 20.000 people, centers of cities and districts and municipalities regardless of their populations may sometimes be accepted as as urban areas. (Bayındırlık ve Ġkan Bakanlığı, 2009: 322, 323 ve 328; Yavuz, KeleĢve Geray, 1973: 23). Turkish Statistical Institute (TSI) has accepted the city centers and district centers as urban areas without taking the population criteria into account. Besides, settled areas out of the centers of cities and districts; subdistricts, subdistric muncipalities, towns and subtowns are not accepted as urban areas. According to the criteria mentioned, in respect to 2009 data of TSI, there are 1818 towns which have a population of 1001 to 2000 people, 246 towns which have a population of 2001-5000 and there ae 5 towns which have a population of over 5001 people. These towns are not accepted as urban areas. These criteria show that the mentioned towns are not accepted as urban areas. An again, in respect to 2009 data of TSI, in Turkey there are 9 districts which have a population of501-1000 people; 44 districts with a population of 1001-2000; 87 districts with population of 2001-3000 and; there are 132 districts with a population of $3001-5000$ people. And thses districts are accepted as urban settlements. ${ }^{\text {ii }}$

In determination of cities, besides these two criteria, some economical and sociological criteria are also considered. According to a pravelant perception in Turkey, rural areas are the settlements in which face to face relations are common, agriculture and stockbreeding are the main economic activities, division of labor and specialization are not well developed, as a result people have difficulties at employment, making their livings nd thus the rate of migration is high (Geray, 1999: 12; Kartal \& Y1lmaz, 2011: 558). And when the concept of city is mentioned people in Turkey visualizes a settlement population is high, immigration rate is high, economic sectors are those out of agriculture, culture, art and sport activities are intense, and expenditures on education, health, substructure, superstructure are on an adequate level. Besides this, it may be made such a generalization that metropolitnas are more urbanized with respect to cities, cities are more urbanized with respect to districts, and districts are moreurbanized with respect to towns (Kartal \& Y1lmaz, 2011: 558).

\section{A Framework of Publi Administration in Turkey}

Although this study aims at analysing "urban administration in Turkey", in order to be able to understand the context, administrative structure of Turkey as whole should be dealed substantially. In the first article of Turkish Constitution it is stated that Turkish State is a 
republic. And in the second article characteristics of the State have been mentioned: "The Republic of Turkey is a democratic, secular and social state governed by rule of law, within the notions of public peace, national solidarity and justice, respecting human rights, loyal to the nationalism of Atatürk, and based on the fundamental tenets set forth in the preamble".

The fifth article of the Constitution mentions the duties of the State: "The fundamental aims and duties of the State are to safeguard the independence and integrity of the Turkish Nation, the indivisibility of the country, the Republic and democracy, to ensure the welfare, peace, and happiness of the individual and society; to strive for the removal of political, economic, and social obstacles which restrict the fundamental rights and freedoms of the individual in a manner incompatible with the principles of justice and of the social state governed by rule of law; and to provide the conditions required for the development of the individual's material and spiritual existence.

The sixth article of the Constitution makes emphasis on republic and democracy: "Sovereignty belongs to the Nation without any restriction or condition.The Turkish Nation shall exercise its sovereignty through the authorized organs, as prescribed by the principles set forth in the Constitution.The exercise of sovereignty shall not be delegated by any means to any individual, group or class. No person or organ shall exercise any state authority that does not emanate from the Constitution."

As it is the case in modern states, also Turkish State also has the functions of legitimation, execution and judiciary, and these three distinct functions are carried out by three distinct organs. In this context, the seventh, eighth and ninth articles are on these functions: The seventh article states that legislative power is vested in the Grand National Assembly of Turkey only on behalf of Turkish Nation. This power shall not be delegated.

The first information in the Constitution about execution power takes place at the eighth article. According to the eight article, executive power and function shall be exercised and carried out by the President of the Republic and the Council of Ministers in conformity with the Constitution and laws. 129th article states that Council of Ministers is consisted of Prime Minister and other ministers. Thus, form the Constitution, it is understood that execution power is consisted of President, Council of Ministers, Prime Minister and other ministers. The nineth article also states that judicial power shall be exercised by independent courts on behalf of the Turkish Nation.

The third part of the Constitution beginning with the 75th article holds more detailed information about main organs of the State. Articles 101 to 137 holds information about formation and functiononig of the executive branch. After mentioning of general principles, under the title of execution, under the title of "administration", general caharacteristics of Turkish bureaucracy out of legislative and judicial bodies have been stated. We can see that President, Council of Ministers, Prime Minister and Ministers who form the executive branch, are at the same time at the top of administration.

Broadly, adminisrative body is a mechanism which performs the duties which have been given to itself by legislative body. In this context administrative body performs these tasks by 
being organised in two seperate forms. This situation is stated in 123rd article of the Constitution. The mentioned article initially states that the administration forms a whole, with regard to its constitution and functions, and then it is stated that the organization and functions of the administration are based on the principles of centralization and decentralization.

Details about organization of the administrative body takes place in some other articles: Art. 126 mentions provincial organization of central administrtaive structure. "Turkey is divided into provinces on the basis of geographical situation, economic conditions, and public service requirements; provinces are further divided into lower levels of administrative districts.The administration of the provinces is based on the principle of devolution of powers."

So, we can say that central administrative stricture has provincial organizations besides its central (Capital) organization. Central administrative units have initially been organized in capital city, and organizations in capital city have duties, authorities and liabilities comprising whole country. Some of the units organized in capital city have no provincial organizations. For example, Presidency and Prime Ministry, Ministries like Foreign Affairs and European Union, and Council of State and Court of Appelas have no provincial organizations. However many of the ministries have provinical (regional, city) organizations. Provincial organizations perform the tasks of the ministries to which they are related, within a limited space.

In Turkey, the concept of provincial organization evokes first of all regional, city, district and subdistrict administrations. Below, more detailed information will take place. Here, we briefly can say that, although there isn't a contrary provision in the Constitution, in practice it does not exist any "region" as administrative unit. Act of Urban Administration No. 5442 mentions subdistricts (bucak) as administrative units other than provinces and districts. However, in practice subdistricts have actually been taken out from Turkish administrative system.

Art. 127 of the Constitution is on local governments. According to this Article, local governments have been defined as "public corporate bodies established to meet the common local needs of the inhabitants of provinces, municipal districts and villages, whose principles of constitution and decision-making organs elected by the electorate are determined by law".

Eelections for local governments are held for every five years. In the Constitution it is also mentioned that special administrative arrangements may be introduced by law for larger urban centres.

There are three seperate local government unit: 1) special provincial administration functioning within whole of the province 2) municipalities functioning within city centers and 3) towns organised in rural areas. ${ }^{\text {iii }}$

\subsection{Capital City (Central) Organization of Central Administration}

As it is mentioned above, central administration in Turkey is divided into capital city units and provincial units. Capital city units consist of President and Presidency, Prime Minister 
and Prime Ministry, Council of Ministers, ministers and ministries and ministries' related organizations. Besides these units, it exists also contributing units like Council of State, Cour of Appelas, Council of National Security; and there are some autonomous authorities within capital city organizations. All these units expres that central administration has the power and authority to determine policies in general and thus, to determine of urban politics. $^{\text {iv }}$

As well some contrary regulation have been made especially in the last decade, centralism is the main caracteristic of Turkish administrative system. So, when talking about effects of capital city administration on provinces, the centralised administrative structure should also be kept in mind. Centralism results in heavy influence of central administration on provinces and provincial administrations. This influence has three dimensions. First, the central administration has the right and authority to determine the politics about cities, within the limits of legislative rules. Central government can use its this right within the limits of legislative rules. But sometimes it can also make a legal arrangement as it was the case when the legal frame about municipal goverments were rearaanged in 2012.

The second influence of central administration on cities is that, central government is mostly the decision making and approval organ of urban policies. Decisions about cities may directly be taken by the central government. Besides this, some of the acts and proceedings (foreign indebtment, establismnet of unions, etc.) of officials of provinces, districts, special provincial administration and municipalities are subject to the approval of central administration.

The third influence of the central government on cities is supervision. It exists a hyerarchical supervision relation between central administration and provincial administrations. And it exists a tutelage supervision relation between central administration and municipalities. In this context, provincial governorships and district governorships which are provincial units of the central administration have to obey to administrative policies of the central administration since they are subalterns of it. It can be said that, in this regard local governments are more autonomous. Nontheless, because of "tutelage supervision" arranged legallly and constitutionally, both central government units and provincial and district governors who are extensions of the central government, have partial tutelage power on local governments.

\subsection{Provincial Extensions of Central Administration: Provinces and Districts}

The provincial administrative units of the central government in Turkey are as follows:

- Regional Administrations

i. Regional Governors (Not actually in blast)

ii. Regional Directorates (Related regional units of Ministries and their affliates)

- Provincial Administration (Valilik, Governorships)

- District Administrations (Kaymakamlık, Provincial governorships); and

- Subdistrict Administrations (Bucak) (Not actually in blast) 
According to Art. 126 of the Consttution, in terms of central administrative structure, Turkey is divided into provinces on the basis of geographical situation, economic conditions, and public service requirements; provinces are further divided into lower levels of administrative districts. "Further lower level" mentioned in the article is arranged by Provincial Administration Act No. 5442. According to this Act, Turkey's administrative structure in urban areas are provinces, districtsand subdistricts. ${ }^{\mathrm{V}}$ And the Constitution permits administrative units as "regional governorships"vi

Here, two points should be mentioned. At this quadruple structure, subdistricts do not actually exist because of dysfunctioning, and it hasn't been established any regional governorship. Even, regional governorships do not exist, in respect to Act 3046, ministries and their affiliates have established regional organizations.

Administrative division in Turkey is based on "province" (Güler, 2011: 240). As a consequence, Tukey has been administratively divided into 81 provinces. ${ }^{\text {vii }}$ Province is an administrative unit which consists of a city center, districts and hundreds of towns. ${ }^{\text {viii }}$ As such, provincial administration includes both urban administration and rural administration. Thus, decision and execution organs of the provinces, serve both in rural and urban areas.

There are three administrative actors at provincial administration system. These are governor, directors of provincial organizations and provincial administrative board.

Head of the provincial administration is governor (vali). ${ }^{\text {ix }}$ Governors are appointed by the Governmnet of Turkey. Governor is both an administrative and political actor. Act of 5442 states that governor is both agent and administrative and political execution agency of the State, of the government and of each minister. As such, governors are administrative head of all public servants except those working in judiciary and military organizations. (Güler, 2011: 256,257;5442: m. 13).

In order to help and to act as his proxy at his absence, vice governors are appointed. These vice governors are selected among lieutenant colonels (kaymakam). In respect to Public Servants' Act No. 657, governorship is stated as "exceptional tenancy", whereas vice governorship and lieutenant colonels are carrier tenants.

There exists a hyerarchical relation between governors and central administration. Prime minister and ministers are superiors of governors (Act 5442 Art. 9). Nevertheless, Art. 126 of the Constitution states that the administration of the provinces is based on the principle of devolution of powers. In respect to this principle, governors representing the State in provinces within the area of authority and responsibility of the State in urban areas, may take decisions and execute these decisions without consulting with central administration.

Provinces are like micro phenomenon of the State in provincial areas. In provinces there are provincial organizations of almost all ministries and their affiliates, and these organizations are under the rule of governor. These provincial directorates serve in urban areas in accordance with rules, plannings and policies of the central administration. Directors are responsible to the governor (Act 5442: Art. 21). 
Related to provincial administration, "provincial administrative board" should be mentioned. Provincial administrative board consists of head of provincial treasury, head of legal affairs, provincial diretors of health, national education, public works, health and agricultre. Governor is head of the board. This board used to serve efficiently, but contemporarily it is not a well functioning board (Güler, 2011: 265)

The secondary provincial organization of central administration is "district" (ilçe). Districts are legally accepted as urban settlements. Districts in Turkey varies with respect to their population, economy, culture, history, etc. There are districts which have population less than 2.000 person, whereas there are districts which have a population of hundreds of thousands of people, and bigger than some provinces. As such, it is difficult to see all the districts as "urban settlemets". However, within Turkish administrative system, districts are settled as "urban settlements".

In Turkey, provinces are divided into districts. So, in Turkey there is no land which is out of territory of a district (city centers are stated as "central district"). Districts are governed by lituenant colonels (kaymakam). Affairs like education, health, security, agriculture, industry and trade, science and technology, culture, tourism, art etc. are under the responsibility of the State. And lituenant colonels are responsible for execution of these affairs in districts, in the name of the State. Lituenant colonels are also head of public servants who work for district organizations of ministries and their affiliates. Like provincial administrative boards of provinces, there are district administrative boards in districts. These boards consist of chief clerk of the district, director of health, director of naional education, director of agriculture and district revenue officer. lituenant colonel is head of the board. As provinces are miniatures of Turkey, districts are miniatures of provinces. Thus, we can, to some extent, say the same things for both provinces and districts.

\section{Local Governments and Cities}

There exist two types of decentralization unit in Turkey. The first unit is the one which serves just for one issue (univerisities and state owned corporations) in whole of the country, and these units are organized functionally. The other unit of decentralization is the one which serves for more than one issue in a limited geographical area. These units are local governments.

Local governments are defined at Art. 127 of the Constitution as "public corporate bodies established to meet the common local needs of the inhabitants of provinces, municipal districts and villages, whose principles of constitution and decision-making organs elected by the electorate are determined by law."

Local governments are not established just in cities or urban areas. Neverteless, at this study local governments established in cities or urban areas will be analysed. In this context, municipalities and special provincial administrations which are local governments at provincial level will be analysed. Analyses of town administrations, which are exact rural administrations will not be included in this study.

Before a detailed analysis of the issue, two concepts about local governments should be 
analysed. The first of these concepts is subsidiarity. Art. 127 of the Constitution sets that "the formation, duties and powers of the local administrations shall be regulated by law in accordance with the principle subsidiarity". Subsidiarity here refers to the local governments to be autonomous, democratic and having legal personality, without carrying any conflict with the rule that "unity of the administration of its foundation and duties" which is set at Art. 123 of the Constitution. As such, local governments serve for meeting local necessities of local community; their decision making and executive organs consist of elected people. They have theirown budgets. They perform their duties and responsibilities given them by the Constitution in respect to laws and Constitution. In this context they take decisions and use initiative freely.

The other concept needing a clear definition is "administrative tutelage". This principle is about regulatory power of the central government on local governments. Art. 127 of the Constitution sets that the central administration has the power of administrative tutelage over the local administrations in the framework of principles and procedures set forth by law with the objective of ensuring the functioning of local services in conformity with the principle of the a) integrity of the administration, b)securing uniform public service, c) safeguarding the public interest and d) meeting local needs properly.

\subsection{Special Provincial Administrations and Cities}

Special provincial administrations are heritages of Ottoman Era to the Republic, and arranged by Regulation of Cities of $1864 .{ }^{\text {xi }}$ With this regulation, special provincial administrations were established as local parliaments, and by the time they have been developed by various special legal arrangements. As aconsequence of an Act made in 1913, these administrative bodies have gained legal personalities. Special provincail administrations as local administrative units have been used effectively in late Ottoman Era and in Republican Era, especially in rural areas. However, even in the period in which these units were used effectively, their authorities have been gradually delegated to central administration. In early 200s, they were almost dysfunctional units (Kartal, 2012: $80 \mathrm{vd}$.).

With the governments established under the leadership of Abduulah Gul and Recep Tayyip Erdopgan, special provincial administrations were tried to be revitalized. With the Act 5302 of Special Provincial Administrations, distinct changes have been realized. With this reform, in order to make these administrative units competent again, their authorities, duties and responsibilities, personnel regimes, budgets and organs have distinctly been changed. However, form 2005 to the present, it is observed that these changes have not positive results at an expected level.

Special provincial administrations have been perceived as local administration of rural areas rather than of urban areas until 2000s. With the Act of 5302, duties and responsibilities on urban areas were also given to these units: In respect to Art. 6 of the Act, SPAs have responsibilitites on the areas as health, youth, industry and trade, landscape panning of the province, public works and settlement, prevention of the land, culture, art, tourism, social services and aids, micro credit fort he poor, orphan asylums, securing areas for building of primary and secondary schools, etc. And these tasks were held by SPAs in both rural and 
urban settlemets of the province. However; zoning, road building, water, sewerage, solid waste, environment, first aid and rescue, support to forest towns, afforestation, park and garden servĢices were the areas for which municipalities were the unique responsible organs. Moreover, the Act sets that "ministries and other central administration units may realize services like building, and maintaining services, state and city roads, drinking water, irrigation water, sewerage, energy transfer lines, health, education, culture, tourism, environment, settlement, youth and sport and other investments within the responsibilities of ministries andother central administration units, in care of special provincial administrations provided that ministries and other units transfer the budget consigned for these services to SPA."

When analysed carefully, it can be seen that SPAs have authority to perform services which are under responsibility of central administration, in whole of the province; wheras it has authority to perform services which are local services in the areas out of municipal territories. It is clear that this arrangement tries to prevent a duty dispute between SPAs and municipalities. Yet, delegation of duties which are under responsibility of central administration also to SPAs is not an administratively consistent practice. This last legal arrangement confirms the critique that SPAs are not actually local governmnet units. On the one hand SPAs are tried to be designed as municipality of the settlements which do not have municipalities, on the other hand SPAs are perceived as a service agent of central administration or governorship.

SPAs are composed of provincial council, provincial borough councillers and governor of the province. Members of provincial council are selected from each district by people. The number of provincial council member of each district is determined in respect to its population. A member of council is elected as the president of the council by members themselves. The operation procedure of SPAs resembles the procedure of Turkish Great National Assembly (Act 5302, Art. 9-24).

Provincial borough councillers who have been entitled for decision and execution of some issues consist of " 5 members of provincial council who are elected for one year by members of the council at a meeting with the presidency of the governor. Voting should be a secret voting. The other five members are the people who have been selected by the governor among administrative units' heads. One of these five people should be the head of financial services". It can be said that provincial borough councillers acts as a bridge between governor and provincial council.

The fact actually important for SPAs is that the governor which is not elected by the people, rather appointed by government of Turkey is head of the provincial organ, and governor acts as executive body. Even the authority of the governor within SPAs have been limited after Act 5302, presidency of an appointed person (governor) at SPAs contradict with autonomous, democratic and free local governmnet discernment.

Dual structure of SPAs, in other words, their location at somwhere between central administration and local government; and duality at their executive structure (appointed governor and elected provincial council), is the fact which actually decreases effectiveness of 
SPAs. MOreover, most people do not have exact information about SPAs. ${ }^{\text {ii }}$ SPA's are called "G் Özel Ġaresi”. And in Turkish "özel” means both special and private. So, because of its name, SPAs are sometimes perceived by some of the people as a privately established unit. We can say that SPAs experience identity crisis. Moreover, it has more problems than autonomy. And it is difficult to mention this much problem, at this study. ${ }^{\text {xii }}$ Briefly we can say that, SPAs are not as efficient and efective as they should be.

\subsection{Municipalities at Adminıstration of Cities}

Municipalties are primary organs within local government system in Turkey. Since main urban services have historically been dealt out by municipalities, municipalities have high rank of visibility and awareness in respect to the people. In Turkey, people actually refer to municipalities when they mention urban administration. Thus, municipalities are perceived as the responsible organ for needs of cities and commoners (gंengül, 2010: 69).

After formation of metropolitan municipalities after 1984, municipalities in Turkey have generally been classified into two main groups. However, with a more systematic perspective we can divide municipalities in Turkey intO five groups:

1. Metropolitian Municipalities

2. Metropolitan District Municipalities (District Municipalities within the territories of metropolitan municipalities).

3. Provincial Municipalities

4. District Municipalities

5. Subdistrict Municipalities

On differences of these groups of municiplaities we can first of all say that, metropolitan municipalities and metropolitan district municipalities are examples of area municipalities. Metropolitan municipalities are responsible for serving within whole territories of a certain province. metropolitan District municipalities are responsible in within territories of just a certain district. But other kind of municipalities are authorised for only a certain settlement. For instance, provincial municipalities are not authorised within whole terrritory of a province, but just within the territories of city center (central district). In a similar vein, a dsitrict municipality is not responsible for municipal services within whole of the district territory, but within the terrritories of central settlement of a certain district. Subdistrict municipalities are the towns who have gained a municipal status. Thus, in a certain district there is just one district municipality, but in addition to this municipality, there may be also subdistrict municipalities within the territories of that district.

Below, municipalities are analysed within two groups: 1) metropolitan municipalities and metropolitan district municipalities 2) Provincial, district and subdistrict municipalities.

\subsection{Metropolıtan Municipalities and Metropolitan District Municipalities}


Besides classical local governments, two tier metropolitan muciaipal system has also been put in practice since 1984. Till 1984, all municipalities were subject to Act of Municipalities No: $1580{ }^{\text {xiv }}$. A municipality with a population of 2000 people and a municipality with a population of over one million people were both governed within the same legal framework. (Eryllmaz, 2013: 203).

1982 Constitution had smoothed the way to establish special government structures for large setttlements. And with a decree law issued in 1984, initially at three municipalities (Ankara, Ġtabul and (்̇mir) metropolitan municipalities were created (Eryllmaz, 2013: 204).Then, in 1986 Adana, in 1987 Bursa, Gaziantep and Konya, in 1988 Kayseri, in 1993 Antalya, Diyarbakır, Erzurum, Eskiç̣hir, Ġmit, Mersin ve Samsun, in 2000 Sakarya were organized as metropolitan municipalities, and the number of metropolitan municipalities reached to 16 (Keser\&Gökmen, 2012: 25). ${ }^{\mathrm{xv}}$ In 2012 with an Act $^{\mathrm{xvi}}$ prepared by Recep Tayyip Erdogan Governmet, important cahnges on metropolitan municipal organizations and administrations were made, and the number of metropolitan municipalities reached to 30 with 14 new metropolitan municipalities. Notable changes with the mentioned act (Act No. 6360) are as follows (Eryılmaz, 2013: 205206):

1. The boundaries of metropolitan municipalities are henceforth boundaries of the provincial administration.

2. Before the Act, in order to be a metropolitan municipality, the sum of population of provincial municipality and the population of settelements which are far from the boundaries of provincial municipality not more than 10.000 meters should be 750.000 in sum. However, after the Act, total population in boundaries of province should be 750.000 in order to be a metropolitan municipality. As a consequence of this arrangements, 14 new metropolitan municipalities were able to be formed.

3. The boundaries of metropolitan district municipalities were widened to boundaries of the whole district. Before, it was boundaries of just central settlement of the district.

4. Special Provincial Administrations in all of the metropolitan municipalities were abolished.

5. Legal personalities of towns within the boundaries of provinces in which metropolitan municipalities exist, are abolished and these towns were transformed into neighbourgood administrations (mahalle muhtarlıkları).

6. Legal personalities of subdistrict municipalities within the boundaries of provinces in which metropolitan municipalities exist, are abolished and these municiplities were transformed into neighbourgood administrations (mahalle muhtarlıkları).

7. Bucak (administrational subdistricts) organizations within the boundaries of metropolitan municipalities were abolished.

Justice and Development Party governments under the leadership of Recep Tayyip Erdoğan aimed at a reorganization at local government system. In accordance with this aim, in 2004 a 


\section{Macrothink}

new Act about metropolitan municipalities was issued. Act No. 3030 which was in effect was abolished and new Metropolitan Municipality Act No. 5216 was issued.

Main duties, reponsibilities and authorities of metropolitan municipalities are as follows: (Act no. 5216: Articles 7-9):

1. Preparing strategical plans;

2. Preparing master zoning plans

3. Licencing and control of business establishments which are or will be active within the boundaries from which metropolitan municipalities are responsible.

4. Preparing master transport plan of metropol.

5. Building of squares, boulevards, avenues and main roads which are within jurisdiction of metropolitan municipality.

6. Establisment of city information and city geographical systems,

7. Protection of environment, farmland and water basins;

8. Afforesting,

9. Services related to solid waste,

10. Performing municipal police services within boundaries in which they are authorized;

11. Building and running passenger and cargo terminals, open and closed parking lots,

12. Building social installations, regional parks, zoos, animal shelters, libraries, museums, sport and entertainment centers which will serve for whole of metropolitan settlers;

13. Supporting amateur sport clubs;

14. Building buildings and plants for health, culture ad education services, material supply and maintanance services for public plants serving the same services to metropolitan settlers;

15. Public transport services,

16. Clean water and sewerage services;

17. Fixing graveyard areas, building and running of graveyards, and services related to interment,

18. Building of wholesale stocks and slaughterhouses

19. Establishment of central heating plants,

20. Generation of land and housing at a needed ratio (Act 5393 Art. 69), 
21. Obtaining urban transformation and development (Act 5393, Art. 73).

Main duties and responsibilities of metropolitan municipalities are as mentioned above. Organs of metropolitan municipalities are "Metropolitan Municpal Parliament" "Metropolitan Municipal Council" and "Metropolitan Mayor".

Metropolitan municipal parliament is the decision making organ of metropolitan municipality. Members of this parliament are not directly elected by people. The parliament consists of one fifth of members of parliaments of district municipalities which are located within the boundaries of metropolitan municipality. Mayors of these districts are also natural members of metropolitan municipal parliament (Eryılmaz, 2013: 207).

Metropolitan municipal council consists of five members of metropolitan municipal parliament who will be selected by the parliament's members themselves for one year; five of the heads of departments of municipality two of whom are general secretary of metropolitan municipality, and head of fiscal affairs. Department heads are elected by metropolitan mayor and mayor is at the same time head of the council. (Act 5216, Art. 16).

"Metropolitan mayor is head of metropolitan municipality organization and he is the representative of legal personality of municipality. Metropolitan mayor is directly elected by electorates resident within the boundaries of metropolitan municipality (Act 5216, Art. 17)."

Metropolitan municipalities in Turkey have been divided into district municipalities in terms of both geography, authority, duty and responsibility. This is the most important difference of metropolitan municipalities and metropolitan district municipalities from other kinds of municipalities. Services which will be performed at a geographical area are distributed among metropolitan municipality, metropolitan district municipality and provincial organizations of central administration. The main duties and responsibilities of metropolitan district municipalities are as follows (Act 5216: Art.. 7):

1.Performing duties and exercising authorities which are not legally given to metropolitan municipality.

2.Collection of rubbage and transfer of it to transfer stations.

3.Licensing and control on certain issues.

4.Building parking lots, sport and entertainment centers and parks;

5.Providing social and cultural services fort he old, the disabled, the woman, the young and the child.

6.Providing vocational training and capability courses.

7.Building and maintainance of sanctuaries, health, education, and culture establishments; and protection of historical properties

8.Providing services in order to develop funtions of spatial locations which are important in terms of history of city. 
9.Providing services related to interment.

10. Collapse and discharge of buildings which are dangerous for life and property security and which entertain disaster risk.

11. Supporting agriculture and stockbreeding.

\section{Municipalities: Provincial, District and Subdistrict Municipalities}

Even they vary in respect to their socio-economical levels, economic developments and populations, municipalities in Turkey out of metropolitan municipalities and metropolitan district municipalities are subject to Act of Municipalities No. 5393 which is issued in $2005^{\mathrm{xvii}}$

The most important difference of provincial, district and subdistrict municipalities from metropolitan municipalities is that, these municipalities are area "belde"xviii municipalities. In other words, these municipalities are of urban settlements. Service area of these municipalities are limited to urban settlements (belde). Within the boundaries which are out of provincial, district or subdistrict municipalities, public services are provided by provincial organizations of central administration and by special provincial administrations.

It is legally possible to establish municipal organizations in settlements population of which are over 5000 people. Besides this, establishment of a municipal organization is compulsory in city or district centers ${ }^{\mathrm{xix}}$ Municipality establishment process in towns differ from the process followed in provinces and districts: Process begins when village council or more than half of electorate of the town makes a written appeal to the administrative chief (in province boundaries governor, and in district boundaries kaymakam). Governor may also start the process exofficio. "In both cases, provincial or district election council realizes an election in the town within 15 days after notification of the governor. Result of this election is not binding. To result of the election, opinion of the governor is attached and both are sent to Ministry of Internal Affairs. After opinion of Coucil of State, municipal organization is established in the mentioned settlement via joint decree ${ }^{x x}$ (müşterek kararname).

Some of the main duties and responsibilities of municipalitites are as follows: (Act 5393: Art. 14); "providing services of urban infrastructure such as development of the region, water and sewage system and transportation; geographical and urban data systems; environment and environmental health, cleaning and solid waste; security forces, fire brigades, emergency aid, relief services and ambulance; city traffic; funeral and cemetery services; forestry, parks and green areas; housing, cultural and artworks, tourism and presentation, youth and sporting activities; social and aid services; marriage ceremonies, professional trainings; and services aimed at development of economy and commerce. The Greater City Municipalities and the municipalities having population more than 50.000 shall open houses for women and children welfare."

Municipalities may also provide following services: "Opening of pre-elementary school education centers; maintenance and repair of school buildings belonging to the Government; procurement of all kinds of equipment/material for this purpose; opening and operation of 
health facilities; protection of cultural and natural resource and places having historical value; repair and maintenance of such places; reconstruction of those ruined same as original. In case of need, providing equipment and support to students and amateur sports clubs, arranging amateur sports matches, giving awards upon decision of municipal council to sportsmen who have been successful in matches performed home or abroad or who have received a degree in matches. Being engaged in food banking."

Municipal services are provided in places closest to the citizens and with most suitable methods. In service providing, suitable methods for disabled, old, bound and poor should be carried out.

In accordance with Turkish administrative structure, there exist three organs in municipalities: Municipal parliament, municipal board and mayor. Municipal parliaments are decision making organs of municipalities and their members are directly eleceted by the voters of locality. (Act 5393: Art. 17). At provincial municipalities and other municipalities which have a population of 10.000 person, municipal board consists of three memeber of municipal parliament who are selected by parliament member themselve; head of fiscal affairs and one of head of the departmnets of municipality who will be elected by mayor. These members of the board are elected for one year. Mayor is head of the board.

Mayor is head of municipal organization and representative of legal personality of municipality. Mayors are directly elected by voters in the location.

When local governments in Turkey are dealt, neighbourhood mukhtars also should be mentioned. Neighbourhood mukhtar was a post in urban areas. But with a legal regulation, towns within the boundaries of metropolitan municipalities were transformed into neighbourhoods. It is difficult to determine the position of neighbourhood mukhtars in Turkish administrative systems. Because, neighbourhood is an intermediate institution organized around both local and central service purposes (Bulut, yıldırım \& g engül, 2000, 179). It carries characteristics of both central and ocal administration. For example, neighbourhoods are administered by mukhtar and neighbourhood board who are both elected directly by the voters. (Act 5393Art.. 9).

The main tasks and duties of neighbourhood mukhtar are determining common needs of neighbourhood settlers; developing life quality of neighbourhood; organizing relation of neighbourhood with municipality and other public institutions; delivering opinion on issues related with neighbourhood; cooperation with other institutions (Act 5393: Art. 9).

\section{Conclusion: Future of City Administrations in Turkey}

At designation of both local governments and provincial organizations of central administration in Turkey, French administrative system has been taken as model (Y1ldirım, gengül \& Bulut, 2002: 341). However, up till now French system has experienced many changes whereas Turkish admnistrative system has stayed steady, centralist and conservative.

After the year 2000, on the issue of city administration some important arrangements have been realised. In acordance with this tendency almost all legal arrangements, out of Act of 
Towns dated back to 1924 and Provincial Administration Act which can be dated back to 1913, even 1864, have been rearranged. Reforms recently realised aims at formation of a plain organization at local level. Abolishment of special provincial addministrations, town legal personalities and small scale municipalities within the bondaries of metropolitan municipalities, may be perceived as consequences of this approach. These abolishments also means ending of dense arguments on special provincial administrations, small scale municipalities and towns. These abolishments at the same time indicates that the Government in Turkey turned away from the policy aiming at increasing functionality of special provincial administrations, towns and small scale municipalities. From statements of Prime Minister Recep Tayyip Erdoğan, we may infer that arrangements on local administration will go on.

At the present situation, provinces and districts are provincial extensions of central administration. At midterm "regional governorships" may be established as it is the case in France. The most important obstacle against regional governorship practice seems as "Kurdish problem". Thus, it is difficult to establish a regional administration unit which adds central adminĢiłration and local government together under one umbrella in near future or midterm. However, a regioal governorship with a local administration under tutelage of regional governorship may be possible in midterm.

Another possible revision at local government system may be such that local governments in Turkey will consist of just municipal organizations. At present, there is no other local administrative unit out of metropolitan municipality at metropolitan municipal areas. The same arrangements may be also valid for other 51 provincial municipalities in Turkey.

Another important rearrangement in Turkey on local administrative system is about scope of local governmnets. With new arrangements municipalities have been edited in a different manner so that municipalities will be able to serve within whole of provincial or district territories rather than city or district centers. Municipalities in Turkey were initially designed as urban administrations. However it seems that there is a tendency about a shift from lurban municipalities to area municipalities.

New arrangements on local administrative system seems to be permanent. Turkey has experienced dysfunctionality of special provincial administrations and towns for a few decades. Abolution of special provincial administrations just after 10 years from their radical rearrangements, and abolution of legal personalities of towns indicate that nothing will be the same in future on the field of city administration. Justice and Development Part has paved a long and wide way of policies on the issues of local governmnets and city administration system. Time will tell the answer of the question that how much will Turkey run on this way.

\section{NOTES}

1. State Planning Organization was established in 1960 and operated under Prime Ministry until 2001. In 2011 it was abolished. Actually, its all task, responsibilties and authorities were transfered to Ministry of Development (see executive order No. 641).

2. Information about "urban-rural difference" and "statistical data" used was taken from Turkish Statistical Institute in context of Act of Information. We, as authors express 


\section{Macrothink}

Journal of Public Administration and Governance

our thanks to staff of the Institute for their urgent and sufficient reply.

3. In recent years, a lot of important changes on this classical local administration system have been realized and standard structure has been changed.

4. Here, it should be mentioned that Prime Minister who is in center of the center has an important role at designation of public policies. Ministers are all selected by Prime Minister. So, it is not difficult for Prime Minister to influence Ministers. In turn, it is not difficult for Cabinet to have influence on the Parliament especially when Party/Parties in power has the majority in Parliament.

5-For the organization of the central administration, Turkey has been divided into provinces, provinces into districts, and districts into subdistricts by geographical situation, economic conditions and requirements of the public service.

6- "Central administrative organizations comprising several provinces may be established to ensure efficiency and coordination of public services. The functions and powers of these organizations shall be regulated by law. (Constitution Art. 126).

7- The number of provinces was 71 when the Republic was founded in 1923. Till 1933 the number of privinces was being decreased. However, after 1933 the number of provinces has a steadily increased (Gürsoy, 2012).

8- Provincial system is a heritage to the Republic from Ottoman Era. Even it had breaking points in time, it should be said that tehere existed a gradual evolution in the system. About history of provincial system in Turkey see: Vecihi Tönük, Türkiye'de Ġlare TeĢkiłtı, Ankara, G̣i Ģ̣̂ri Bakanlığı yayını, 1945, s. 52; đ̇mail Hakkı Göreli, Ġ đ̇aresi, Ankara, A.Ü. SBF yayını, 1952, s. 15; đ̈ber Ortayl1, Tanzimattan Sonra Mahalli Ġareleri (1840-1878), Ankara, TODAĆE yayın1, 1974, s. 39; RuĢenKeleĢve Fehmi Yavuz Yerel Yönetimler, Ankara, Turhan Kitapevi, 1983, s. 42; Muzaffer Sencer Osmanlı Ġmparatorluğunda Tanzimat Sonrası Siyasal ve Yönetsel GeliĢmele”, Amme Ġlaresi Dergisi, Cilt 17, Sayı 3, (Eylül 1984), ss. 46-71, s. 54; Ahmet Nohutçu, Kamu Yönetimi, 7. Baskı, Ankara, SavaĢYayınevi, 2011, s 110.

9- Governors are apointed by a triple process. First, they are elected by Ministry of Internal Affairs, then comes decision of Council of Ministers and last step is approval of The President. (Act 5442: Art. 6).

10-Exceptional tenancy is arranged at 59th, 60th and 61st Articles of Pblic Servants Act. At 59th Article it si stated which tenancies are exceptional. Persons who has the eligibility to be appointed as a public servant, may be appointed to exceptional tenancy posts. In general no special terms are required for these positions.

11- For detailed information about special provincial administrations see,: Kartal, 2012. 
12- About the issue Kartal writes that (2012: 79): "Information level of citizens about special provincial organizations is low. If people are not aware of an institution it will be difficult to qualify that institution as a democratic local government unit. Researches carried out about the subject show that citizens are aware of SPAs, even menay of them haven't heard its name before. About awareness of SPAs among Turkish sciety, see: TOBB, 1996: 174,175; CoĢkun \&Uzun, 2004: 68

13- About these problems see: Kartal, 2012: 75-81.

14- This Act was in effect till 2005. In 2005 Municpalitry Act No: 5393 was issued and it is still in effect.

15-Moreover, at three of Metropolitan municipalities names of the Provinces and Central Districts were not the same. With Act 4764 which was issued in 2002,

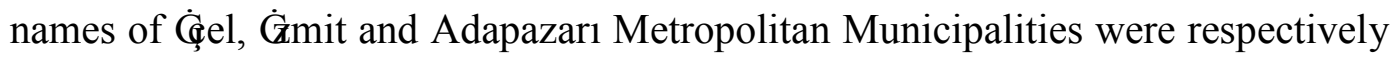
changed into Mersin, Kocaeli nd Sakarya (Keser \& Gökmen, 2012: 25).

16- With Act No. 6360 which was issued on 12.11.2012 in Aydın, Balıkesir, Denizli, Hatay, Malatya, Manisa, KahramanmaraĢ, Mardin, Muğla, Ordu, Tekirdağ, Trabzon, ganliurfa ve Van Metropolitan Municipalities were established. For text of law see: http://www.mevzuat.gov.tr/Kanunlar.aspx Access: 03.04.2014.

17- Metropolitan Municipalities and Metropolitan Daistrict Municipalities are subject to Metropolitan Municipality Act No. 5216. In case it exists a loophole at this Act, they will be subject to Municipality Act No. 5393.

18-In Turkish administrative system "belde" refers to "a settlement with municipal organization" (Act 5393 Art. 3), municipalities with the name "belde municipalities" are theones which are established in towns within bordering of a certain district.

19- This legal rule mostly has been ill-used by citizens and politicians. Settlements (towns) which do not meet criterium of population have been made a district and thus establishment of municipal organization has been made compulsory.

20- Joint decree which is an administrative act, is an act signatures of related Minister, Prime Minister and the President alltogether take placein the Act. The other kind is Cabinet Decree at which signature of all Ministers, Prime Minister and the President take place.

\section{References}

BAYINDIRLIK VE (̇ंKÂN BAKANLIĞI (2009), KentleĢmeg̉urası Komisyon Raporları II. Cilt, Ankara: Bayındırlık Ve Ġkân Bakanlığı Yayını

BULUT, Yakup, Yıldırım, Uğur \& ġengül, Ramazan (2002), Mahalle Muhtarlıklarının Belediye Yönetimleri Gie CiiĢkiłri: Gaziantep ve KahramanmaraĢÖrneği, Yerel Yönetimler Sempozyum Bildirileri, TODAC̈́⿺ Yayını, 177-192. 


\section{Macrothink}

Journal of Public Administration and Governance ISSN 2161-7104 2015, Vol. 5, No. 1

COg்KUN, Bayram \& Uzun, Turgay (2004), đ́ Özel Ġlaresi Reformuna GịĢin Bazı Değerlendirmeler, Yerel Yönetimler Kongresi: Dünden Bugüne Yerel Yönetimlerde Yeniden Yapılanma, Pozitif Matbaacilık, 67-77.

ERYILMAZ, Bilal (2013), Kamu Yöntimi: DüĢüceler, Yapılar, Fonksiyonlar, Politikalar, 6. Baskı, Kocaeli: Umuttepe Yayınları

GERAY, Cevat (1999), Kırsal Kalkınma Yöneltileri, Ǵçe Yerel Yönetimi Ve “Gíçe Köy Birlikleri” Önerisi, ÇağdaĢYerel Yönetimler Dergisi, Cilt 9, Sayı, 3, 3-24.

GÜLER, Birgül Ayman (2011), Türkiye’nin Yönetimi: Yap1, 3. Bask1, Ankara: đ̇̀nge.

GÜRSOY, Erol Zihni (2008), "Cumhuriyet Döneminde Yeni Ġ Ve Ġlẹ Kurulmasında YaklaĢınlar”, Türk Ġlare Dergisi, Sayı 458, 81-94.

KARTAL, Nazım \& Demirhan Yılmaz (2011), Kırsal Yoksulluktan Kentsel Yoksulluğa, Uluslararası Yoksullukla Mücadele Stratejileri Sempozyumu: Deneyimler Ve Yeni Fikirler (13-15 Ekim2010), BaÇbakanlık Sosyal YardımlaĢma Ve DayanıĢnæ Genel Müdürlüğü Yayın1,

KARTAL, Nazım (2012), Türkiye'de đ̇ Özel Ġlareleri, Ağrı, Ağrı đ̇̉rahim Çeçen Üniversitei Yayınlar1

KESER, Ahmet \& Gökmen, Yunus (2012), ÇağdaĢYerel Yönetimler Dergisi, Cilt 21, Say1 $1,17-42$.

gENGÜL Ramazan (2010) Yerel Yönetimler, Kocaeli: Umuttepe Yayınları

ġENGÜL, Tarık (2009), Kentsel Çelişki Ve Siyaset. Ankara: Ġinge Yayınevi.

TEKELG̣ Ċinan (2009), Modernizm, Modernite Ve Türkiye'nin Kent Planlama Tarihi. đ̇tanbul: Tarih Vakfi Yayınları.

TOBB (1996), Mahalli İdarelerin Yeniden Yapılandırılması, Ankara: TOBB Yayını,

TOBB (Türkiye Odalar Ve Borsalar Birliği) 1996), Mahalli Ġdaelerin Yeniden Yapılandırılması, Ankara TOBB Yayını

YAVUZ, Fehmi, KeleĢ, RuĢen\&Geray, Cevat (1973), ġehircilik: Sorunlar - Uygulama Ve Politika, Ankara: Ankara Üniversitesi, Siyasal Bilgiler Fakültesi Yayınları.

YILDIRIM, Uğur, ġengül, Ramazan \& Bulut, Yakup (2002), Türkiye đ̣in Yeni Bir Model Önerisi: Bölge Yönetimi, Yerel Yönetimler Sempozyum Bildirileri, Ankara: Todaie Yayını, 333-345.

\section{LEGISLATION}

(For whole of legislation see http://www.mevzuat.gov.tr/Kanunlar.aspx

Act 5442 Provincial Administration Act, Official Journal Date: 18.06.1949, Sayısı: 7236

Act 3046 Official Journal Date: 09.10.1984Sayısı: 18540 


\section{Macrothink}

Act 3056 Act of Prime Ministry Organization

1982 constitution

Act 657 Public Servants Act

Act 5302 Special Provincial Administration Act.

Act 5216 Metroploitan Municipality Act

Act 5393 Act of Municipality

Decree Law No. 641.

Act No.4764

Act No.6360 